\title{
PERAN KEMANDIRIAN DAN KECERDASAN EMOSIONAL TERHADAP PENYESUAIAN DIRI PADA SISWA ASRAMA TAHUN PERTAMA SMK KESEHATAN BALI MEDIKA DENPASAR
}

\author{
Ni Kadek Wulandari dan I Made Rustika \\ Program Studi Psikologi, Fakultas Kedokteran, Universitas Udayana \\ kd.wulandari@yahoo.com
}

\begin{abstract}
Abstrak
Penyesuaian diri adalah proses yang mencakup seluruh kemampuan individu baik tingkah laku maupun respon mental dalam menyelaraskan kebutuhan dan tuntutan yang berasal dari dalam diri maupun dari lingkungan. Kemampuan dalam penyesuaian diri sangat diperlukan karena membantu individu dalam menghadapi berbagai perubahan dan tuntutan dari lingkungan. Penyesuaian diri diperlukan siswa tahun pertama dalam menghadapi masa transisi sekolah khususnya bagi siswa yang menempuh pendidikan di sekolah asrama. Penyesuaian diri dipengaruhi oleh kemampuan dalam pengelolaan emosi dan kesiapan mental dalam menyelesaikan masalah tanpa bantuan dari orang lain. Penelitian ini bertujuan untuk melihat peran dari kemandirian dan kecerdasan emosional terhadap penyesuaian diri pada siswa asrama tahun pertama. Subjek pada penelitian ini berjumlah 125 siswa kelas X dari SMK Kesehatan Bali Medika Denpasar. Alat ukur penelitian yang digunakan adalah skala penyesuaian diri, skala kecerdasan emosional dan skala kemandirian. Hasil dari uji analisis regresi berganda menunjukkan nilai $\mathrm{R}=0,783$ $(\mathrm{p}<0,05)$ dan $\mathrm{R} 2=0,613$ sehingga dapat disimpulkan bahwa kemandirian dan kecerdasan emosional bersama-sama berperan sebesar $61,3 \%$ terhadap penyesuaian diri pada siswa asrama. Koefisien beta terstandarisasi dari kemandirian menunjukkan nilai sebesar 0,296 ( $\mathrm{p}<0,05)$ yang berarti bahwa kemandirian berpengaruh secara signifikan terhadap penyesuaian diri. Koefisien beta terstandarisasi dari kecerdasan emosional menunjukkan nilai sebesar $0,541(p<0,05)$ yang berarti bahwa kecerdasan emosional berpengaruh secara signifikan terhadap penyesuaian diri.
\end{abstract}

Kata kunci: kemandirian, kecerdasan emosional, penyesuaian diri, siswa asrama, tahun pertama

\begin{abstract}
Personal Adjustment is a process which includes all the individual behavior and mental response in harmonize needs and demands in which it is derived from the inside of individual as well as from the environment. The ability in personal adjustment is needed to help the individual in facing many changes and demands from the environment. Personal adjustment is needed for first-year students in facing the school's transition, especially for the students who proceed their education in a boarding school. Personal adjustment is affected by the ability in managing the emotion and mental readiness to solve a problem without a help from others. This research is aimed to explore the role of autonomy and emotional intelligence to the personal adjustment in the first-year boarding students. The subjects were 125 boarding students in grade X of SMK Kesehatan Bali Medika Denpasar. The instrument in the research were personal adjustment scale, autonomy scale and emotional intelligence scale. The results of multiple regression analysis showed the value of $\mathrm{R}=0,783(\mathrm{p}<0,05)$ and $\mathrm{R} 2=0,613$, which concluded that the personal adjustment and emotional intelligence conjunctly contributes as much as $61,3 \%$ to the personal adjustment in th first-year boarding students. Standardized beta coefficient of autonomy showed the value of $0,296(p<0,05)$, which concluded that the autonomy contribute to the personal adjustment. Standardized beta coefficient of emotional intelligence showed the value of $0,541(\mathrm{p}<0,05)$, which concluded that the emotional intelligence contribute to the personal adjustment.
\end{abstract}

Keywords: autonomy, emotional intelligence, personal adjustment, boarding students, first-year 


\section{KEMANDIRIAN DAN KECERDASAN EMOSIONAL TERHADAP PENYESUAIAN DIRI SISWA ASRAMA TAHUN PERTAMA}

\section{LATAR BELAKANG}

Manusia sebagai individu pada hakekatnya terus tumbuh dan berkembang di sepanjang kehidupannya. Individu melewati serangkaian tahapan perkembangan yang berawal dari masa kanak-kanak hingga lanjut usia. Setiap tahapan perkembangan tidak dapat dikatakan sebagai tahapan yang terputus, melainkan hubungan yang erat dan saling memengaruhi antara yang satu dengan selanjutnya (Hurlock, 1980). Tugas perkembangan pada setiap tahapan berbedabeda, sehingga individu dihadapkan pada perubahan yang tidak hanya berasal dari aspek biologis namun juga aspek kognitif, lingkungan dan sosio-emosional. Kemampuan dalam penyesuaian diri sangat diperlukan karena membantu individu dalam menghadapi dan mengatasi berbagai perubahan, tuntutan bahkan permasalahan dalam setiap tahapan. Menurut Agustiani (2009), individu akan mampu mengatasi berbagai permasalahan yang dialami apabila memiliki kemampuan penyesuaian diri.

Schneiders (1964) mengemukakan bahwa penyesuaian diri adalah suatu proses mencakup respon-respon mental dan tingkah laku, yang merupakan usaha individu agar berhasil mengatasi kebutuhan, ketegangan, konflik dan frustrasi yang dialami di dalam dirinya. Menurut Calhoun \& Acocella (1990) penyesuaian dapat didefinisikan sebagai interaksi yang berkelanjutan antara diri sendiri, orang lain dan dengan dunia. Ketiga faktor ini secara konsisten memengaruhi individu dan bersifat timbal balik. Schneiders (dalam Agustiani, 2009) juga mengatakan bahwa individu yang dapat menyesuaikan diri dengan baik adalah individu yang dengan keterbatasan pada diri, belajar untuk bereaksi terhadap diri dan lingkungan dengan cara yang matang, bermanfaat, efisien, memuaskan, serta dapat menyelesaikan konflik, frustrasi, maupun kesulitan-kesulitan pribadi dan sosial tanpa mengalami gangguan tingkah laku.

Berbagai transisi pada setiap tahapan perkembangan dilewati oleh individu, salah satunya adalah transisi sekolah. Santrock (2007b) berpendapat bahwa transisi memasuki sekolah menengah atas dari sekolah menengah pertama dapat menimbulkan stres pada siswa karena terjadi banyak perubahan tidak hanya di dalam diri individu tetapi juga di dalam keluarga dan sekolah. Hal ini dapat menjadi situasi yang sulit bagi banyak siswa. Perubahan-perubahan ini mencakup hal-hal yang berkaitan dengan perubahan dalam kognisi sosial, meningkatnya tanggung jawab dan menurunnya ketergantungan pada orangtua, memasuki struktur sekolah yang lebih besar, perubahan dari kelompok teman yang kecil menjadi kelompok teman yang lebih besar serta meningkatnya fokus pada prestasi dan performa (Santrock, 2007b). Penyesuaian diri bagi siswa tahun pertama sekolah menengah atas sangatlah penting untuk dimiliki siswa dalam menghadapi perubahan, khususnya bagi siswa yang mengenyam pendidikan di sekolah berasrama.

Tinggal di asrama selama tiga tahun dan jauh dari orangtua tidak mudah bagi sebagian besar siswa. Lingkungan asrama yang asing bagi siswa dengan teman dan orang-orang yang baru dikenal, berbagai aturan asrama yang akan membatasi perilaku siswa dan berbagai pekerjaan yang harus diselesaikan sendiri dapat menjadi tekanan tersendiri bagi siswa. Menurut Vembriarto (dalam Setiawan, 2013) sekolah berasrama merupakan model sekolah yang memiliki tuntutan yang lebih tinggi bila dibandingkan dengan sekolah reguler. Tuntutan lain yang dialami oleh siswa yaitu ekspektasi yang tinggi dari orangtua, mampu disiplin dan mandiri dalam menjalani pendidikan dan kehidupan di asrama. Salah satu sekolah menengah atas yang menerapkan sistem pendidikan berasrama adalah SMK Kesehatan Bali Medika Denpasar.

Berdasarkan hasil studi pendahuluan yang dilakukan kepada 63 siswa kelas X SMK Kesehatan Bali Medika Denpasar, diperoleh bahwa 42 siswa mengalami kesulitan dalam menyesuaikan diri dengan kehidupan di asrama. Hambatan yang dialami oleh para siswa antara lain adalah lingkungan baru dengan teman-teman baru, kondisi yang jauh dari orangtua dan sistem pembelajaran yang diterapkan. Siswa merasakan kesulitan dalam menjalin hubungan sosial dengan teman-teman sebaya, merasakan perubahan atau penurunan kondisi fisik, psikis, motivasi berprestasi, serta sulitnya berkonsentrasi ketika belajar karena kondisi asrama yang bising. Hasil studi pendahuluan juga menunjukkan bahwa beberapa siswa mampu mengatasi hambatan dan kesulitan yang dihadapi dengan cara meminta saran atau pendapat dari orangtua, meminta saran atau pendapat dari teman, meminta saran atau pendapat dari guru BK dan terdapat beberapa siswa yang lebih memilih untuk menemukan sendiri pemecahan masalah yang dialami (Wulandari, 2016).

Sejalan dengan pemaparan di atas, hasil penelitian Wahab, dkk. (2013) yang dilakukan pada 350 siswa sekolah asrama di Kuala Lumpur, Malaysia terdapat 39,7\% siswa mengalami depresi, $67,1 \%$ siswa mengalami kecemasan dan $44,9 \%$ siswa mengalami stres. Faktor-faktor yang memengaruhi tingkat depresi, kecemasan dan stres pada siswa terkait sistem pendidikan akademik, guru, hubungan intrapersonal, hubungan interpersonal, proses belajar mengajar, dan kelompok sosial. Sistem pendidikan akademik dan hubungan intrapersonal merupakan prediktor paling besar sebagai stressor yang dapat mengakibatkan depresi, kecemasan dan stres pada siswa. Masalah psikologis dapat dialami oleh siswa dan akan berdampak kepada motivasi dan prestasi siswa dalam menjalani kehidupan pendidikan di asrama. Menurut Ryan dan Deci (2000b), kondisi sosial dan lingkungan individu berperan dalam meningkatkan motivasi pada diri. 
Menurut Setiawan (2013) peserta didik yang mengikuti pendidikan di sekolah berasrama memerlukan kemampuan penyesuaian diri dan kemauan yang besar untuk mengikuti setiap kegiatan yang dilaksanakan selama pendidikan. Kondisi fisik, mental dan emosional siswa dipengaruhi oleh bagaimana siswa mampu menyesuaikan diri dengan lingkungan. Siswa yang memiliki penyesuaian yang baik akan mampu menghadapi keadaan yang sulit dengan penyelesaian yang positif (Fatimah, 2006). Mendukung pemaparan di atas, Calhoun \& Acocella (1990) juga berpendapat bahwa penyesuaian diri terhadap tuntutan dan perubahan sangat diperlukan remaja sebagai mekanisme yang efektif untuk mengatasi stres dan terhindar dari terjadinya masalah psikologis.

Siswa akan lebih mudah dalam mengidentifikasi pemecahan-pemecahan masalah yang dialami selama menjalani kehidupan pendidikan di asrama ketika siswa mampu melakukan penyesuaian diri dengan baik. Penelitian Zakiyah, Hidayati dan Setyawan (2010) diperoleh bahwa ketidakmampuan siswa dalam menyesuaikan diri akan memengaruhi munculnya ketegangan dan konflik dalam diri individu yang dapat memicu munculnya perilaku prokrastinasi akademik. Prokrastinasi terjadi tidak hanya dikarenakan oleh manajemen waktu dan kebiasaan belajar yang buruk tetapi juga dipengaruhi oleh kognitif, perilaku dan perasaan (Solomon \& Rothblum, 1984). Keberhasilan penyesuaian diri siswa pada tahun pertama menentukan penyesuaian diri siswa pada tahun-tahun berikutnya. Berdasarkan pemaparan di atas, timbul pertanyaan mengapa terdapat siswa yang mampu untuk menyesuaikan diri dan ada yang tidak mampu menyesuaikan diri di lingkungan asrama sekolah.

Penyesuaian diri siswa di lingkungan asrama dipengaruhi oleh kesiapan mental siswa untuk mampu menghadapi dan menyelesaikan berbagai permasalahan tanpa bantuan orangtua ataupun orang lain. Kesiapan mental tersebut erat kaitannya dengan kemampuan individu dalam mencapai kemandirian. Kemandirian menurut Steinberg (2014) adalah kemampuan untuk melakukan dan mempertanggungjawabkan tindakan yang dilakukan serta menjalin hubungan yang suportif dengan orang lain. Kemandirian menurut Desmita (2009) merupakan kecakapan yang berkembang sepanjang rentang kehidupan individu, yang sangat dipengaruhi oleh faktor-faktor pengalaman dan pendidikan. Steinberg (2014) membagi kemandirian dalam tiga aspek yaitu kemandirian emosional, kemandirian perilaku dan kemandirian kognitif. Kemandirian emosional adalah perubahan kelekatan hubungan emosional yang terjadi antara individu dengan orang lain seperti hubungan emosional dengan anggota keluarga khususnya orangtua.

Siswa dapat dikatakan telah memiliki kemandirian emosional apabila siswa mampu untuk melepaskan diri dari ketergantungan secara emosional dengan orangtua atau orang dewasa lain. Sekolah asrama menuntut siswa untuk jauh dari orangtua dan lingkungan keluarga. Siswa harus tinggal dan menetap selama tiga tahun di lingkungan baru dan bersama orang-orang baru. Siswa akan lebih mudah untuk beradaptasi dan menyesuaikan diri di lingkungan asrama ketika siswa mampu untuk mengembangkan kemandirian emosional. Perasaan memiliki dan menjadi bagian dari lingkungan asrama akan tumbuh pada diri siswa bersamaan dengan proses penyesuaian diri siswa. Siswa yang memiliki perasaan yang kuat sebagai bagian dari sekolah akan lebih mampu menyesuaikan diri dengan kehidupan akademik, meminimalisir adanya gejala depresi, penyesuaian sosial dan motivasi akademik yang lebih baik (Goodenow, 1993). Siswa tidak akan merasa frustrasi dan tertekan ketika harus berjauhan dengan orangtua atau figur lekat ketika menghadapi suatu masalah di asrama, siswa akan mampu bereaksi dan menyelesaikan permasalahan yang dihadapi secara rasional.

Kemandirian emosi tidak sama dengan kemandirian perilaku. Kemandirian perilaku menurut Steinberg (2014) adalah kemampuan untuk membuat keputusan tanpa tergantung pada orang lain dan melakukannya secara bertanggung jawab. Kehidupan asrama menuntut siswa untuk dapat menjalankan aktivitas dan menyelesaikan permasalahan yang dialami secara mandiri tanpa adanya campur tangan orang lain. Kemandirian perilaku tidak hanya tercermin dari tingkah laku siswa yang mampu melakukan segala hal sendiri tetapi juga mampu untuk bertanggung jawab dalam segala tindakan yang dilakukan. Kemampuan siswa dalam mengarahkan diri ketika harus mempertimbangkan suatu pemecahan masalah atau konflik akan terhambat apabila siswa tidak mampu dalam melakukan kemandirian perilaku.

Selain kemandirian, faktor lain yang dapat memengaruhi penyesuaian diri pada individu adalah perkembangan dan kematangan individu dalam segi intelektual, sosial, moral, dan emosi. Menurut Santrock (2007a) pada masa remaja, individu cenderung lebih menyadari siklus emosionalnya. Goleman mengemukakan bahwa emosi merujuk kepada suatu perasaan dan pikiranpikiran yang khas, suatu keadaan biologis, psikologis dan serangkaian kecenderungan untuk bertindak. Keberhasilan atau kegagalan individu dalam mengelola emosinya tergantung pada kecerdasan emosional. Semakin tinggi kecerdasan emosional, maka individu akan semakin mampu untuk mengatasi berbagai masalah, khususnya yang memerlukan kendali emosi yang kuat (Goleman, 2015). Kecerdasan emosional sangatlah penting dimiliki oleh siswa dalam menghadapi masa transisi ini.

Meningkatnya kemampuan kognitif dan kesadaran diri pada masa remaja dapat membantu dalam mengatasi permasalahan psikologis dan fluktuasi emosional secara lebih efektif. Kesadaran dan pengendalian emosi berperan dalam hal ini. Goleman (2015) menyebutkan bahwa kesadaran diri 


\section{KEMANDIRIAN DAN KECERDASAN EMOSIONAL TERHADAP PENYESUAIAN DIRI SISWA ASRAMA}

TAHUN PERTAMA

merujuk kepada kemampuan individu dalam mengenali emosi sehingga tidak terjebak dan dikuasai oleh perasaannya sendiri. Pengendalian emosi dapat membantu individu untuk menyeimbangkan emosi agar dapat tersampaikan atau terungkapkan dengan cara yang tepat. Kehidupan asrama di tahun pertama tidak mudah. Lingkungan baru yang terdiri dari guru, pegawai dan teman-teman baru menuntut siswa untuk belajar bersosialisasi dan mengakrabkan diri. Siswa dituntut untuk dapat menjalin dan membangun hubungan pertemanan baru di lingkungan asrama dimana siswa lebih banyak menghabiskan waktu bersama teman sebaya baik di sekolah maupun di asrama.

Siswa harus mampu menampilkan kesan positif sehingga dapat diterima dalam lingkungan teman di asrama pada saat siswa mulai membangun hubungan pertemanan yang baru. Menurut Islami (2016), penerimaan yang dirasakan dari siswa dapat membantu siswa untuk lebih menerima pengaruh positif yang diberikan dari lingkungan, sehingga siswa dapat lebih mudah dalam beradaptasi dengan peraturan dan meminimalisir terjadinya perilaku yang menyimpang. Kemampuan keterampilan sosial dapat membantu siswa untuk berinteraksi dalam suatu hubungan sosial. Tidak selalu terjadi persamaan pendapat yang membuat interaksi berjalan lancar pada setiap interaksi. Siswa harus mampu mengendalikan emosi agar tidak terjebak dan dikuasai oleh emosi negatif yang dirasakan ketika terjadi perbedaan pendapat.

Pentingnya pengendalian dan ketenangan emosi dapat membantu individu dalam menghadapi permasalahan secara cermat dan dapat membantu dalam menentukan berbagai pemecahan masalah ketika menemui hambatan (Schneider, 1964). Apabila siswa mengalami emosi yang berlebihan dan tidak mampu mengendalikan, hal tersebut dapat memicu siswa untuk melampiaskan emosi secara tidak rasional dan berujung pada terjadinya konflik.

Berdasarkan permasalahan-permasalahan yang telah dipaparkan, peneliti ingin mengetahui apakah terdapat peran dari kemandirian dan kecerdasan emosional terhadap penyesuaian diri pada siswa asrama tahun pertama SMK Kesehatan Bali Medika Denpasar dan apakah kemandirian dan kecerdasan emosional secara masing-masing berperan terhadap penyesuaian diri pada siswa asrama tahun pertama SMK Kesehatan Bali Medika Denpasar. Penelitian ini diharapkan dapat memberikan manfaat secara teoritis dalam pengembangan ilmu Psikologi Pendidikan dan Psikologi Perkembangan. Penelitian ini juga diharapkan mampu memberikan manfaat praktis bagi siswa dan orangtua dalam menambah pemahaman dan memberikan informasi mengenai kemandirian dan kecerdasan emosional terkait dengan penyesuaian diri siswa asrama. Penelitian ini diharapkan mampu memberikan manfaat bagi instansi pendidikan dalam menambah pemahaman dan informasi terkait peran kemandirian dan kecerdasan emosional terhadap penyesuaian diri siswa sehingga dapat memfasilitasi dalam pembuatan suatu program pelatihan, kegiatan maupun ekstrakurikuler bagi siswa. Penelitian ini diharapkan dapat menjadi referensi peyusunan penelitian terkait kemandirian, kecerdasan emosional dan penyesuaian diri siswa asrama dan menjadi pembanding bagi penelitian selanjutnya.

\section{METODE}

\section{Variabel dan definisi operasional}

Variabel bebas dalam penelitian ini adalah kemandirian dan kecerdasan emosional serta variabel tergantung dalam penelitian ini adalah penyesuaian diri.

Definisi operasional dari masing-masing variabel dalam penelitian ini sebagai berikut:

\section{Penyesuaian Diri}

Penyesuaian diri adalah proses yang mencakup seluruh kemampuan individu baik tingkah laku maupun respon mental dalam menyelaraskan kebutuhan dan tuntutan yang berasal dari dalam diri maupun dari lingkungan sehingga tercapai keharmonisan. Taraf penyesuaian diri diukur dengan skala penyesuaian diri, semakin tinggi skor total maka semakin tinggi tingkat kemampuan penyesuaian diri.

\section{Kemandirian}

Kemandirian adalah suatu kemampuan individu dalam menentukan dan mempertanggungjawabkan segala tindakan yang dilakukan atas dasar pertimbangan personal tanpa adanya pengaruh dari orangtua ataupun orang lain. Taraf kemandirian diukur dengan skala kemandirian, semakin tinggi skor total maka semakin tinggi taraf kemandirian.

\section{Kecerdasan Emosional}

Kecerdasan emosional adalah suatu kemampuan yang dimiliki oleh individu untuk memahami, menggunakan emosi, mengelola emosi dan mengendalikan emosi agar dapat memotivasi diri dan bertahan dalam menghadapi stres dan frustrasi untuk semakin memperkuat pertumbuhan dan perkembangan kepribadian individu. Taraf kecerdasan emosional diukur dengan skala kecerdasan emosional, semakin tinggi skor total maka semakin tinggi taraf kecerdasan emosional.

\section{Responden}

Populasi penelitian menggunakan siswa kelas $\mathrm{X}$ SMK Kesehatan Bali Medika Denpasar yang berjumlah 156 orang. Karakteristik populasi dalam penelitian ini adalah sebagai berikut:

1. Menempuh pendidikan di SMK Kesehatan Bali Medika Denpasar. 
2. Tinggal di asrama sekolah selama menempuh pendidikan.

Teknik pengambilan sampel dalam penelitian ini adalah sampling jenuh, yaitu semua populasi digunakan sebagai sampel penelitian dikarenakan jumlah sampel yang relatif kecil sebesar 156 orang. Pada proses pengambilan data jumlah skala yang disebar sebanyak 156 skala, namun hanya 125 skala yang memenuhi syarat kelengkapan untuk dapat dilakukan analisis data.

\section{Tempat Penelitian}

Penelitian dilakukan di SMK Kesehatan Bali Medika Denpasar. Pengambilan data dilakukan sebanyak dua kali yaitu pertama pada tanggal 27 April 2016 di kelas X A-A, P-A dan P-B SMK Kesehatan Bali Medika Denpasar. Pengambilan data kedua pada tanggal 2 Mei 2016 di kelas X P-C dan P-D SMK Kesehatan Bali Medika Denpasar.

\section{Alat Ukur}

Alat ukur penelitian ini menggunakan tiga skala yaitu, skala penyesuaian diri, skala kemandirian dan skala kecerdasan emosional. Skala penyesuaian diri dimodifikasi dari skala Sasmita (2015) yang mengacu pada aspek penyesuaian diri Schneiders (1964), skala kemandirian disusun sendiri oleh peneliti dengan mengacu pada aspek kemandirian Steinberg (2014), dan skala kecerdasan emosional dimodifikasi dari skala Rustika (2014) yang mengacu pada teori Goleman (2000).

Skala penyesuaian diri terdiri dari 32 item pernyataan, skala kemandirian terdiri dari 28 item pernyataan, dan skala kecerdasan emosional terdiri dari 20 item pernyataan. Pernyataan pada skala penelitian ini tediri dari kalimat positif (favorable) dan kalimat negatif (unfavorable) yang disediakan dalam empat pilihan jawaban yaitu Sangat Sesuai (SS), Sesuai (S), Tidak Sesuai (TS) dan Sangat Tidak Sesuai (STS).

Alat ukur yang valid dan reliabel merupakan syarat mutlak untuk mampu menghasilkan data dan memberikan informasi yang akurat (Azwar, 2014). Pada penelitian ini, uji validitas alat ukur penelitian diuji dengan cara mengeliminasi item-item yang memiliki korelasi item total sama dengan atau kurang dari 0,30 ( $\leq 0,30)$. Menurut Azwar (2014), apabila jumlah item yang valid belum mencukupi jumlah yang diinginkan, batas kriteria dapat diturunkan menjadi 0,25 sehingga jumlah item yang diinginkan tercapai. Uji reliabilitas alat ukur pada penelitian ini dilakukan dengan metode Cronbach's Alpha. Semakin tinggi koefisien Alpha $(\alpha)$ mengindikasikan semakin reliabel suatu skala. Alat ukur dikatakan reliabel apabila skor reliabilitasnya lebih besar dari $0,60(\geq 0,60)$.
Penyebaran skala untuk uji coba alat ukur dilaksanakan sebanyak dua kali yaitu pertama pada tanggal 31 Maret 2016 di SMK Kesehatan Bali Khresna Medika dan SMK Kesehatan Bali Dewata. Pada uji coba pertama, skala kemandirian tidak memenuhi syarat validitas dan reliabilitas sehingga dilakukan uji coba kedua skala kemandirian pada tanggal 12 April 2016 di SMK Kesehatan Bali Dewata.

Hasil uji validitas skala penyesuaian diri menunjukkan nilai koefisien korelasi item total bergerak dari 0,261 - 0,640. Hasil uji reliabilitas skala penyesuaian diri menunjukkan koefisien Alpha $(\alpha)$ adalah sebesar 0,871 yang berarti bahwa skala ini mampu mencerminkan $87,1 \%$ variasi skor murni subjek, sehingga dapat disimpulkan bahwa skala penyesuaian diri layak digunakan sebagai alat ukur untuk mengukur taraf penyesuaian diri.

Hasil uji validitas skala kemandirian menunjukkan nilai koefisien korelasi item total bergerak dari 0,270 - 0,610. Hasil uji reliabilitas skala kemandirian menunjukkan koefisien Alpha $(\alpha)$ adalah sebesar 0,859 yang berarti bahwa skala ini mampu mencerminkan $85,9 \%$ variasi skor murni subjek, sehingga dapat disimpulkan bahwa skala kemandirian layak digunakan sebagai alat ukur untuk mengukur taraf kemandirian.

Hasil uji validitas skala kecerdasan emosional menunjukkan nilai koefisien korelasi item total bergerak dari 0,269 - 0,637. Hasil uji reliabilitas skala kecerdasan emosional menunjukkan koefisien Alpha $(\alpha)$ adalah sebesar 0,851yang berarti bahwa skala ini mampu mencerminkan $85,1 \%$ variasi skor murni subjek, sehingga dapat disimpulkan bahwa skala kecerdasan emosional layak digunakan sebagai alat ukur untuk mengukur taraf kecerdasan emosional.

\section{Teknik Analisis data}

Pengujian hipotesis dilakukan setelah data penelitian terlebih dahulu melewati syarat uji asumsi yaitu uji normalitas, uji linearitas, dan uji multikolinearitas. Pada penelitian ini uji normalitas menggunakan uji Kolmogorov Smirnov, uji linearitas dilakukan menggunakan uji Compare Means dan uji multikolinearitas dilakukan dengan melihat nilai Variance Inflation Factor (VIF) dan Tolerance. Setelah melakukan uji asumsi, data penelitian dianalisis dengan menggunakan metode analisis regresi berganda untuk menguji hipotesis mayor dan hipotesis minor. Analisis data dilakukan dengan menggunakan bantuan perangkat lunak SPSS 20.0 for Windows. 


\section{KEMANDIRIAN DAN KECERDASAN EMOSIONAL TERHADAP PENYESUAIAN DIRI SISWA ASRAMA TAHUN PERTAMA}

\section{HASIL PENELITIAN}

\section{Karakteristik Subjek}

Berdasarkan data karakteristik subjek diperoleh bahwa total subjek berjumlah 125 orang yang terdiri dari 9 laki-laki dan 116 perempuan. Orangtua subjek memiliki tingkat pendidikan yang beragam yaitu SD, SMP, SMA atau SMK, diploma, S1 dan S2. Mayoritas orangtua subjek berpendidikan sekolah menengah atas atau sederajat dengan persentase sebesar $67,2 \%$ pada ayah dan $58,4 \%$ pada ibu. Berdasarkan urutan kelahiran, mayoritas subjek adalah anak sulung dengan persentase sebesar $52 \%$.

\section{Deskripsi Data Penelitian}

Hasil deskripsi data penelitian yaitu penyesuaian diri, kemandirian dan kecerdasan emosional dapat dilihat pada tabel 1 .

\begin{tabular}{cccccccc}
\multicolumn{8}{c}{$\begin{array}{c}\text { Tabel 1 } \\
\text { Deskripsi data penelitian }\end{array}$} \\
\hline Variabel & $\mathrm{N}$ & $\begin{array}{c}\text { Mean } \\
\text { Teoritis }\end{array}$ & $\begin{array}{c}\text { Mean } \\
\text { Empiris }\end{array}$ & $\begin{array}{c}\text { Std Deviasi } \\
\text { Teoritis }\end{array}$ & $\begin{array}{c}\text { Std Deviasi } \\
\text { Empiris }\end{array}$ & $\begin{array}{c}\text { Sebaran } \\
\text { Teoritis }\end{array}$ & $\begin{array}{c}\text { Sebaran } \\
\text { Empiris }\end{array}$ \\
\hline PD & 125 & 80 & 100,46 & 16 & 8,405 & $32-128$ & $80-118$ \\
\hline $\mathrm{Kem}$ & 125 & 70 & 80,23 & 14 & 7,549 & $28-112$ & $50-99$ \\
\hline $\mathrm{KE}$ & 125 & 50 & 56,97 & 10 & 6,294 & $20-80$ & $42-73$ \\
\hline
\end{tabular}

Pada tabel 1 dapat dilihat bahwa penyesuaian diri memiliki mean teoritis yang lebih besar dari mean empiris sehingga menghasilkan perbedaan sebesar 20,46. Mean empiris lebih besar dari mean teoritis (mean empiris > mean teoritis) sehingga dapat disimpulkan bahwa subjek memiliki penyesuaian diri yang tinggi. Rentang skor subjek penelitian berkisar antara 80 sampai 118 yang berdasarkan penyebaran frekuensi 99,2\% subjek berada di atas mean teoritis.

Pada tabel 1 dapat dilihat bahwa kemandirian memiliki mean teoritis yang lebih besar dari mean empiris sehingga menghasilkan perbedaan sebesar 10,23. Mean empiris lebih besar dari mean teoritis (mean empiris > mean teoritis) sehingga dapat disimpulkan bahwa subjek memiliki kemandirian yang tinggi. Rentang skor subjek penelitian berkisar antara 50 sampai 99 yang berdasarkan penyebaran frekuensi $92 \%$ subjek berada di atas mean teoritis.

Pada tabel 1 dapat dilihat bahwa kecerdasan emosional memiliki mean teoritis yang lebih besar dari mean empiris sehingga menghasilkan perbedaan sebesar 6,97. Mean empiris lebih besar dari mean teoritis (mean empiris > mean teoritis) sehingga dapat disimpulkan bahwa subjek memiliki kecerdasan emosional yang tinggi. Rentang skor subjek penelitian berkisar antara 42 sampai 73 yang berdasarkan penyebaran frekuensi $84,8 \%$ subjek berada di atas mean teoritis.

\section{Uji Asumsi}

\begin{tabular}{ccc}
\multicolumn{2}{c}{ Tabel 2 } \\
& \multicolumn{2}{c}{ Uji normalitas data penelitian } \\
\hline Variabel & Kolmogorof-Smirnov Z & Asymp. Sig. (2-tailed) \\
& & $(\mathrm{P})$ \\
\hline Penyesuaian Diri & 0,783 & $\mathbf{0 , 5 7 2}$ \\
Kemandirian & 0,629 & $\mathbf{0 , 8 2 4}$ \\
Kecerdasan Emosional & 0,996 & $\mathbf{0 , 2 7 5}$ \\
\hline
\end{tabular}

Uji normalitas pada penelitian ini menggunakan Kolmogorov Smirnov dengan bantuan perangkat lunak SPSS 20.0 for Windows. Data dikatakan normal apabila nilai signifikansi lebih besar dari 0,05 ( $p>0,05)$ (Santoso, 2005). Pada tabel 2 dapat diketahui bahwa data pada variabel penyesuaian diri berdistribusi normal dengan nilai Kolmogorof-Smirnov sebesar 0,783 dan signifikansi 0,572 ( $p>0,05$ ). Data pada variabel kemandirian berdistribusi normal dengan nilai Kolmogorof-Smirnov sebesar 0,629 dan signifikansi $0,824(p>0,05)$. Data pada variabel kecerdasan emosional berdistribusi normal dengan nilai KolmogorofSmirnov sebesar 0,996 dan signifikansi 0,275 ( $p>0,05)$.

\begin{tabular}{|c|c|c|c|c|}
\hline \multicolumn{5}{|c|}{$\begin{array}{c}\text { Tabel } 3 \\
\text { Uji linearitas data penelitian }\end{array}$} \\
\hline & & & $\mathrm{F}$ & Sig. \\
\hline & \multirow{3}{*}{$\begin{array}{l}\text { Between } \\
\text { Groups }\end{array}$} & (Combined) & 4.277 &, 000 \\
\hline $\begin{array}{l}\text { Penyesuaian } \\
\text { Diri* }\end{array}$ & & Linearity & 108,930 & ,000 \\
\hline Kemandirian & & $\begin{array}{l}\text { Deviation from } \\
\text { Linearity }\end{array}$ & 0,901 & 619 \\
\hline Penyesuaian & \multirow{3}{*}{$\begin{array}{l}\text { Between } \\
\text { Groups }\end{array}$} & (Combined) & 6,120 &, 000 \\
\hline Diri * & & Linearity & 150,004 & ,000 \\
\hline $\begin{array}{l}\text { Kecerdasan } \\
\text { Emosional }\end{array}$ & & $\begin{array}{l}\text { Deviation from } \\
\text { Linearity }\end{array}$ & 0,586 & 940 \\
\hline
\end{tabular}

Uji linearitas bertujuan untuk mengetahui adanya hubungan yang linear antara variabel bebas dengan variabel tergantung (Ghozali, 2005). Uji linearitas pada penelitian ini menggunakan uji Compare Mean dengan melihat nilai signifikansi pada Linearity kurang dari $0,05 \quad(\mathrm{p}<0,05)$ (Priyatno, 2012). Uji linearitas dilakukan dengan bantuan perangkat lunak SPSS 20.0 for Windows. Pada tabel 3 dapat diketahui bahwa pada variabel penyesuaian diri dengan kemandirian memiliki nilai signifikansi Linearity sebesar $0,000 \quad(\mathrm{p}<0,05)$. Pada variabel penyesuaian diri dengan kecerdasan emosional memiliki nilai signifikansi Linearity sebesar 0,000 $(\mathrm{p}<0,05)$. Pada uji linearitas dapat disimpulkan bahwa terdapat hubungan yang linear antara penyesuaian diri dengan kemandirian dan penyesuaian diri dengan kecerdasan emosional.

\begin{tabular}{|c|c|c|c|c|}
\hline \multirow{3}{*}{ Model } & \multicolumn{3}{|c|}{$\begin{array}{c}\text { Tabel 4 } \\
\text { Uji multikolinearitas data penelitian }\end{array}$} & \multirow{3}{*}{ Keterangan } \\
\hline & \multirow{2}{*}{ Signifikansi } & \multicolumn{2}{|c|}{ Collinearity Statistics } & \\
\hline & & Tolerance & VIF & \\
\hline Kemandirian &, 000 & ,468 & 2,135 & $\begin{array}{c}\text { Tidak ada } \\
\text { multikolinearitas }\end{array}$ \\
\hline $\begin{array}{c}\text { Kecerdasan } \\
\text { Emosional }\end{array}$ & ,000 & ,468 & 2,135 & $\begin{array}{l}\text { Tidak ada } \\
\text { multikolinearitas }\end{array}$ \\
\hline
\end{tabular}

Uji multikolinearitas bertujuan untuk mengetahui apakah terdapat korelasi yang tinggi antara variabel bebas. Metode regresi dianggap baik ketika variabel bebas tidak 
memiliki korelasi yang tinggi, hal tersebut dapat dilihat dari nilai VIF kurang dari $10(<10)$ dan nilai Collinearity Tolerance lebih besar dari $0,1 \quad(>0,1)$ (Ghozali, 2005). Uji multikolinearitas dilakukan dengan bantuan perangkat lunak SPSS 20.0 for Windows. Pada tabel 4 dapat dilihat bahwa nilai Tolerance sebesar 0,468 $(>0,1)$ dan nilai VIF sebesar $2,135(<10)$, sehingga dapat disimpulkan tidak terdapat multikolinearitas atau tidak ada hubungan yang linear antar variabel bebas yaitu kemandirian dan kecerdasan emosional.

Berdasarkan hasil uji asumsi yang telah dilakukan, diperoleh bahwa data penelitian ini memiliki distribusi normal, memiliki hubungan yang linear, dan tidak terjadi multikolinearitas antara variabel bebas.

\section{Uji Hipotesis}

Hasil uji regresi berganda variabel kemandirian dan kecerdasan emosional terhadap penyesuaian diri adalah sebagai berikut:

\begin{tabular}{cccc} 
& \multicolumn{2}{c}{$\begin{array}{c}\text { Tabel 5 } \\
\text { Hasil uji regresi berganda data penelitian }\end{array}$} \\
\hline $\mathrm{R}$ & $\mathrm{R}$ Square & Adjusted R Square & $\begin{array}{c}\text { Std. Error of the } \\
\text { Estimate }\end{array}$ \\
\hline $\mathbf{0 , 7 8 3}$ & $\mathbf{0 , 6 1 3}$ & 0,607 & 5,272 \\
\hline
\end{tabular}

Uji hipotesis digunakan untuk mengetahui apakah hipotesis yang diajukan pada penelitian diterima atau ditolak (Santoso, 2005). Pada penelitian ini, uji hipotesis menggunakan metode analisis regresi berganda (multiple regression) dengan bantuan perangkat lunak SPSS 20.0 for Windows. Pada tabel 5 dapat hubungan yang terjadi antara variabel bebas dan variabel tergantung pada nilai koefisien regresi (R) sebesar 0,783 dengan koefisien determinasi ( $R$ Square) sebesar 0,613, yang berarti bahwa kemandirian dan kecerdasan emosional memberikan sumbangan efektif sebesar $61,3 \%$ terhadap penyesuaian diri, sedangkan $38,7 \%$ dipengaruhi oleh faktor lain yang tidak diteliti dalam penelitian ini.

\begin{tabular}{lrrrrr}
\multicolumn{7}{c}{ Tabel 6 } \\
& Hasil uji regresi berganda signifikansi nilai F & \\
\hline Model & Sum of & & & F & Sig. \\
\hline Regression & 5368,674 & 2 & 2684,337 & 96,595 &, 000 \\
Residual & 3390,334 & 122 & 27,790 & & \\
Total & 8759,008 & 124 & & & \\
\hline
\end{tabular}

Pada tabel 6, diperoleh $\mathrm{F}$ hitung adalah 96,595 dengan taraf signifikansi $0,000(<0,05)$ sehingga model regresi dapat digunakan untuk memprediksi penyesuaian diri. Berdasarkan hasil di atas dapat disimpulkan bahwa kemandirian dan kecerdasan emosional secara bersama-sama berperan terhadap penyesuaian diri.
Tabel 7

\begin{tabular}{|c|c|c|c|c|c|}
\hline \multirow[t]{2}{*}{ Model } & \multicolumn{2}{|c|}{$\begin{array}{c}\text { Unstandardized } \\
\text { Coefficients }\end{array}$} & \multirow{2}{*}{$\begin{array}{c}\begin{array}{c}\text { Standardized } \\
\text { Coefficients }\end{array} \\
\text { Beta }\end{array}$} & \multirow[t]{2}{*}{$\mathrm{t}$} & \multirow[t]{2}{*}{ Sig. } \\
\hline & B & Std. Error & & & \\
\hline (Constant) & 32,913 & 5,133 & & 6,412 & .000 \\
\hline Kemandirian & ,329 &, 092 & 296 & 3,591 & .000 \\
\hline Kecerdasan Emosional &, 722 &, 110 &, 541 & 6,570 & .000 \\
\hline
\end{tabular}

Pada tabel 7 dapat dilihat bahwa kemandirian memiliki koefisien beta terstandarisasi sebesar 0,296 dengan nilai $\mathrm{t}$ sebesar 3,591 dan memiliki taraf signifikansi sebesar $0,000 \quad(<0,05)$ yang menunjukkan bahwa kemandirian berpengaruh secara signifikan terhadap penyesuaian diri. Variabel kecerdasan emosional memiliki koefisien beta terstandarisasi sebesar 0,541 dengan nilai t sebesar 6,570 dan memiliki taraf signifikansi sebesar $0,000 \quad(<0,05)$ yang menunjukkan bahwa kecerdasan emosional berpengaruh secara signifikan terhadap penyesuaian diri. Berdasarkan hasil diatas, dapat disebutkan bahwa variabel kecerdasan emosional mempunyai pengaruh lebih besar terhadap penyesuaian diri dibandingkan dengan kemandirian.

Hasil uji regresi berganda pada tabel 7 juga dapat memprediksi taraf penyesuaian diri dari masing-masing subjek dengan melihat persamaan garis regresi sebagai berikut:

$Y=32,913+0,329 \times 1+0,722 \times 2$

\section{Keterangan :}

$\mathrm{Y}=$ Penyesuaian Diri

$\mathrm{X} 1=$ Kemandirian

$\mathrm{X} 2=$ Kecerdasan Emosional

a. Konstanta sebesar 32,913 menyatakan bahwa jika tidak ada penambahan atau peningkatan skor pada kemandirian ataupun kecerdasan emosional maka taraf penyesuaian diri sebesar 32,913.

b. Koefisien regresi X1 sebesar 0,329 menyatakan bahwa pada setiap penambahan atau peningkatan satuan skor subjek pada variabel kemandirian, maka akan terjadi kenaikan taraf penyesuaian diri sebesar 0,329 .

c. Koefisien regresi X2 sebesar 0,722 menyatakan bahwa pada setiap penambahan atau peningkatan satuan skor subjek pada variabel kecerdasan emosional, maka akan terjadi kenaikan taraf penyesuaian diri sebesar 0,722.

Ringkasan hasil uji terhadap hipotesis mayor dan hipotesis minor pada penelitian ini dapat dilihat pada tabel 8 . 


\begin{tabular}{clc}
\multicolumn{3}{c}{ Tabel 8 } \\
\multicolumn{3}{c}{ Rangkuman hasil uji hipotesis penelitian } \\
\hline No & \multicolumn{1}{c}{ Hipotesis } & Hasil \\
\hline 1 & $\begin{array}{l}\text { Hipotesis Mayor: } \\
\text { Kemandirian dan kecerdasan emosional berperan } \\
\text { terhadap penyesuaian diri pada siswa asrama tahun } \\
\text { pertama SMK Kesehatan Bali Medika Denpasar }\end{array}$ & Diterima \\
\hline 2 & $\begin{array}{l}\text { Hipotesis Minor: } \\
\text { a. Kemandirian berperan terhadap penyesuaian diri pada } \\
\text { siswa asrama tahun pertama SMK Kesehatan Bali } \\
\text { Medika Denpasar. }\end{array}$ & Diterima \\
& \\
& b. Kecerdasan emosional berperan terhadap penyesuaian \\
& diri pada siswa asrama tahun pertama SMK Kesehatan & Diterima \\
& Bali Medika Denpasar. & \\
\hline
\end{tabular}

\section{Uji Data Tambahan}

Penelitian ini melakukan analisis data tambahan dari data demografi subjek penelitian. Uji data tambahan bertujuan untuk melihat apakah terdapat perbedaan penyesuaian diri ditinjau dari jenis kelamin, pendidikan ayah dan pendidikan ibu.

\section{a. Penyesuaian Diri Ditinjau dari Jenis Kelamin}

Subjek penelitian dikelompokkan menjadi dua kategori yaitu perempuan (P) dan laki-laki (L). Pengujian hipotesis dalam uji data tambahan ini menggunakan uji komparasi parametrik yaitu independent sample t-test pada program SPSS 20.0 for Windows. Hasil uji independent sample t-test dapat diihat pada tabel 9.

\begin{tabular}{ccc}
\multicolumn{3}{c}{ Tabel 9} \\
Hasil uji penyesuaian diri ditinjau dari jenis kelamin \\
\hline Independent Sample t-Test & Sig. 2-tailed & Keterangan \\
\hline Penyesuaian Diri & 0,387 & Tidak ada perbedaan \\
\hline
\end{tabular}

Pada tabel 9 diperoleh skor probabilitas adalah 0,387 $(>0,05)$. Hal ini berarti tidak ada perbedaan yang signifikan pada penyesuaian diri ditinjau dari jenis kelamin.

\section{b. Penyesuaian Diri Ditinjau dari Pendidikan Ayah}

Subjek penelitian dikelompokkan menjadi dua kategori yaitu pendidikan dasar dan pendidikan tinggi. Pengujian hipotesis dalam uji data tambahan ini menggunakan uji komparasi parametrik yaitu independent sample t-test pada program SPSS 20.0 for Windows. Hasil uji independent sample t-test dapat dilihat pada tabel 10 .

\begin{tabular}{ccc}
\multicolumn{2}{c}{ Tabel 10 } \\
Hasil uji penyesuaian diri ditinjau dari pendidikan ayah \\
\hline Independent Sample t-Test & Sig. 2-tailed & Keterangan \\
\hline Penyesuaian Diri & 0,835 & Tidak ada perbedaan \\
\hline
\end{tabular}

Pada tabel 10 diperoleh skor probabilitas adalah 0,835 (>0,05). Hal ini berarti tidak ada perbedaan yang signifikan pada penyesuaian diri ditinjau dari pendidikan ayah.

\section{c. Penyesuaian Diri Ditinjau dari Pendidikan Ibu}

Subjek penelitian dikelompokkan menjadi dua kategori yaitu pendidikan dasar dan pendidikan tinggi. Pengujian hipotesis dalam uji data tambahan ini menggunakan uji komparasi parametrik yaitu independent sample t-test pada program SPSS 20.0 for Windows. Hasil uji independent sample t-test dapat dilihat pada tabel 11 .
Tabel 11

Hasil uji penyesuaian diri ditinjau dari pendidikan ibu

\begin{tabular}{lll}
\hline Independent Sample t-Test & Sig. 2-tailed & Keterangan \\
\hline Penyesuaian Diri & 0,137 & Tidak ada perbedaan \\
\hline
\end{tabular}

\section{PEMBAHASAN DAN KESIMPULAN}

Berdasarkan hasil penelitian yang telah dilakukan dan dianalisis dengan menggunakan teknik analisis regresi berganda, dapat diketahui bahwa pengujian hipotesis adanya peran yang signifikan dari kemandirian dan kecerdasan emosional terhadap penyesuaian diri pada siswa asrama tahun pertama SMK Kesehatan Bali Medika Denpasar dapat diterima. Hal ini dapat dilihat dari nilai koefisien regresi (R) dalam penelitian ini sebesar 0,783 dengan $F$ hitung sebesar 96,595 dengan taraf signifikansi 0,000 $(<0,05)$ menunjukkan bahwa kemandirian dan kecerdasan emosional secara bersama-sama berperan terhadap penyesuaian diri.

Koefisien determinasi sebesar 0,613 yang menunjukkan bahwa kedua variabel bebas yaitu kemandirian dan kecerdasan emosional memberikan sumbangan efektif sebesar $61,3 \%$ terhadap penyesuaian diri. Maka dapat ditarik kesimpulan bahwa kemandirian dan kecerdasan emosional menentukan $61,3 \%$ penyesuaian diri yang dimiliki oleh siswa asrama tahun pertama SMK Kesehatan Bali Medika Denpasar, sedangkan 38,7\% dipengaruhi oleh variabel atau faktor lain yang tidak diteliti dalam penelitian ini. Pada koefisien beta terstandarisasi, diketahui bahwa kemandirian dan kecerdasan emosional secara mandiri memiliki peran terhadap penyesuaian diri. Variabel kemandirian memiliki koefisien beta terstandarisasi sebesar 0,296 dengan nilai t sebesar 3,591 dan memiliki taraf signifikansi sebesar 0,000 $(<0,05)$ yang menunjukkan bahwa kemandirian berpengaruh secara signifikan terhadap penyesuaian diri. Variabel kecerdasan emosional memiliki koefisien beta terstandarisasi sebesar 0,541 dengan nilai $\mathrm{t}$ sebesar 6,570 dan memiliki taraf signifikansi sebesar $0,000 \quad(<0,05)$ yang berarti bahwa kecerdasan emosional berpengaruh secara signifikan terhadap penyesuaian diri.

Berdasarkan hasil koefisien beta terstandarisasi, dapat diketahui bahwa variabel bebas yang lebih berpengaruh terhadap penyesuaian diri adalah kecerdasan emosional. Kecerdasan emosional lebih berpengaruh terhadap penyesuaian diri bila dibandingkan dengan kemandirian karena individu dengan kecerdasan emosional yang tinggi memiliki kemampuan untuk mengendalikan emosi diri, kesadaran akan emosi, kemampuan dalam memahami perasaan orang lain, adanya motivasi diri dan kemampuan dalam berhubungan sosial. Kemampuan tersebut tidak hanya membuat individu dapat bertindak dengan lebih baik dan efektif, tetapi juga membuat lingkungan di sekitar individu lebih nyaman dalam berinteraksi ataupun menjalin hubungan sosial yang baik. Kehidupan asrama menuntut siswa untuk 
mampu menyesuaikan diri tidak hanya dengan kondisi asrama namun juga dengan warga asrama yaitu pembina asrama dan teman-teman sebaya.

Siswa dengan kecerdasan emosional yang tinggi memiliki kemampuan dalam memahami dan berinteraksi sosial dengan baik. Kemampuan siswa dalam memahami perasaan orang lain akan membuat siswa mampu menjaga segala perilaku ataupun tutur kata yang digunakan sehingga tidak menimbulkan adanya kesalahpahaman ataupun konflik yang berujung kepada hubungan sosial yang terganggu. Siswa lebih mudah dalam membangun atau membina hubungan sosial dengan teman ataupun guru di asrama dengan kemampuan tersebut. Siswa dengan kecerdasan emosional yang tinggi juga memiliki kemampuan untuk berhati-hati dalam setiap pengambilan keputusan pemecahan masalah dan memiliki kemampuan dalam mengandalikan emosi secara lebih efektif. Siswa dengan kendali emosi yang kuat dapat mengontrol diri dalam menghadapi masalah sehingga tidak menimbulkan perilaku negatif.

Menurut Goleman (2015), semakin tinggi kecerdasan emosional, maka individu akan semakin mampu untuk mengatasi berbagai masalah khususnya yang memerlukan kendali emosi yang kuat. Mendukung pemaparan Goleman (2015), Schneiders (1964) menyebutkan bahwa keadaan mental yang baik akan mendorong individu untuk memberikan respon yang selaras dengan dorongan internal maupun tuntutan lingkungannya. Sejalan dengan pemaparan di atas, hasil penelitian Saptoto (2010) menunjukkan kecerdasan emosional memiliki pengaruh terhadap kemampuan coping adaptif pada remaja. Individu yang memiliki kecerdasan emosional tinggi akan segera mengenali perubahan emosi dan penyebabnya ketika menghadapi stres atau konflik yang menekan,. Individu mampu menggali emosi tersebut secara obyektif, sehingga tidak larut ke dalam emosi. Hal ini membuat individu mampu memikirkan berbagai cara coping untuk meredakan stres dan menyelesaikan konflik yang sedang berlangsung.

Sama halnya dengan kecerdasan emosional, kemandirian juga berpengaruh terhadap penyesuaian diri siswa asrama namun dengan koefisien beta terstandarisasi lebih kecil dibandingkan dengan kecerdasan emosional. Hal ini dapat terjadi karena, individu dengan kemandirian yang tinggi akan lebih berfokus kepada diri sendiri dalam pencapaian suatu tujuan. Siswa memiliki perasaan bahwa kemampuan personal akan dirasa mampu untuk membuat siswa mencapai tujuan yang diharapkan, meskipun tanpa adanya bantuan dari teman-teman di lingkungan asrama. Siswa dengan kemandirian yang tinggi mampu untuk menyesuaikan diri dengan kondisi asrama yang mengharuskan siswa jauh dari orangtua dan tidak akan mengalami kesedihan yang berlarut-larut ketika berpisah dengan orangtua. Siswa dengan kemandirian yang baik juga lebih mudah dalam menyesuaikan diri dengan tuntutan untuk mampu melakukan segala hal tanpa mengandalkan orang lain seperti mencuci pakaian, membersihkan kamar, menyetrika pakaian dan sebagainya.

Pada deskripsi data penelitian, variabel kecerdasan emosional memiliki mean teoritis sebesar 50 dan mean empiris sebesar 56,97 (mean empiris > mean teoritis) yang menunjukkan bahwa siswa asrama tahun pertama SMK Kesehatan Bali Medika Denpasar memiliki taraf kecerdasan emosional yang tinggi. Hasil kategorisasi data kecerdasan emosional menunjukkan bahwa mayoritas subjek memiliki taraf kecerdasan emosional tinggi sebanyak 64 orang $(51,2 \%)$. Tingginya kemampuan kecerdasan emosional siswa asrama dapat dikaji dari peran lingkungan sekolah dalam memaksimalkan pendidikan karakter siswa melalui ekstrakurikuler pramuka yang wajib diikuti oleh seluruh siswa. Pramuka adalah salah satu kegiatan sekolah yang bertujuan untuk menumbuhkan karakter siswa ke arah yang lebih positif. Sejalan dengan hal tersebut, dalam penelitian Purwandari dan Purwati (2008) diperoleh bahwa pendidikan karakter berbasis pendidikan nilai dapat meningkatkan kemampuan kecerdasan emosional pada anak. Pendidikan nilai yang dapat memengaruhi kecerdasan emosi atau bahkan aspek lain akan lebih efektif apabila tidak hanya merupakan pengajaran, akan tetapi proses pembelajaran dan pelatihan. Anak tidak hanya mengetahui tentang prinsip hidup akan tetapi anak belajar menjadi seorang yang mempunyai prinsip.

Kegiatan pramuka seperti berkemah, mencari tanda jejak dan sebagainya mampu melatih siswa mengendalikan emosi dalam penyelesaian suatu permasalahan, menumbuhkan rasa empati terhadap sesama teman dan bekerjasama dalam mencapai suatu tujuan kelompok. Siswa akan dihadapkan pada suatu tugas yang harus diselesaikan dalam berkelompok, sehingga siswa harus mengendalikan emosi diri sehingga mampu dengan jernih mengidentifikasi pemecahan masalah yang paling sesuai. Pada saat melakukan kegiatan namun ada salah satu anggota yang mengalami kesulitan, siswa akan terlatih untuk memiliki rasa empati tanpa harus mengabaikan teman yang mengalami kesulitan namun tetap mencapai tujuan kelompok secara bersama-sama. Dazeva dan Tarmidi (2012) dalam penelitiannya mengemukakan bahwa siswa yang mengikuti ekstrakurikuler yang melibatkan perilaku prososial memiliki kecerdasan emosi yang tinggi. Sejalan dengan penelitian Dazeva dan Tarmidi (2012), dalam penelitian Puspitasari (2015) diperoleh hasil bahwa siswa yang mengikuti ekstrakurikuler pramuka memiliki kecerdasan emosional yang cenderung tinggi.

Pada deskripsi data penelitian, variabel kemandirian memiliki mean teoritis sebesar 70 dan mean empiris sebesar 80,23 (mean empiris > mean teoritis) yang menunjukkan bahwa siswa asrama tahun pertama SMK Kesehatan Bali Medika Denpasar memiliki taraf kemandirian yang tinggi. Hasil 


\section{KEMANDIRIAN DAN KECERDASAN EMOSIONAL TERHADAP PENYESUAIAN DIRI SISWA ASRAMA}

TAHUN PERTAMA

kategorisasi data kemandirian menunjukkan bahwa mayoritas subjek memiliki taraf kemandirian tinggi yaitu sebanyak 69 orang $(55,2 \%)$. Tingginya kemampuan kemandirian siswa asrama dapat dipengaruhi oleh pola sistem pendidikan asrama yang dijalani oleh siswa. Steinberg (2014) berpendapat bahwa remaja yang memperoleh kemandirian adalah remaja yang dapat memiliki kemampuan untuk mengatur diri sendiri secara bertanggung jawab, meskipun tidak ada pengawasan dari orangtua. Situasi ini menyebabkan remaja memiliki tanggung jawab baru mengenai dirinya dan tidak bergantung kepada orangtua. Kehidupan asrama yang menuntut siswa untuk jauh dari orangtua menghadapkan siswa pada suatu tanggung jawab untuk dapat melakukan segala hal tanpa mengandalkan orang lain. Selama menempuh pendidikan di SMK Kesehatan Bali Medika Denpasar, siswa dituntut untuk mampu melakukan hal-hal kecil secara mandiri seperti mencuci pakaian, membersihkan kamar dan menyetrika pakaian. Siswa dibagi ke dalam beberapa kelompok piket yang bertugas untuk membersihkan kamar, dan ruang kelas.

Pada penelitian ini, karakteristik subjek berdasarkan urutan kelahiran mayoritas siswa adalah anak sulung atau anak pertama sebesar 65 orang (52\%). Dikuatkan dengan perkembangan kemandirian menurut Desmita (2009), orangtua pada umumnya memiliki sikap, perlakuan dan memberikan peran yang spesifik terhadap anak tunggal, anak sulung, anak tengah, atau anak bungsu. Hurlock (1980) menambahkan bahwa, posisi sebagai anak sulung ataupun anak bungsu merupakan posisi yang istimewa dalam keluarga. Anak sulung akan diberi tanggung jawab oleh orangtua untuk menjaga saudaranya, dan dituntut untuk dapat menjadi role model yang baik bagi saudaranya. Berbagai hal tersebut membuat anak sulung lebih memiliki kemampuan dalam kemandirian bila dibandingkan dengan anak tengah dan anak bungsu. Sejalan dengan pemaparan di atas, Rini (2012) dalam penelitiannya mengungkapkan bahwa urutan kelahiran anak dalam keluarga juga menentukan bagaimana kemampuan kemandirian pada anak. Kemandirian anak sulung tentu akan berbeda dengan anak bungsu dikarenakan adanya perbedaan dalam memperlakukan diri seorang anak yang diperoleh dari lingkungan, orangtua dan orang terdekat.

Pada deskripsi data penelitian, variabel penyesuaian diri memiliki mean teoritis sebesar 80 dan mean empiris sebesar 100,46 (mean empiris > mean teoritis) yang menunjukkan bahwa siswa asrama tahun pertama SMK Kesehatan Bali Medika Denpasar memiliki taraf penyesuaian diri yang tinggi. Hasil kategorisasi data penyesuaian diri menunjukkan bahwa mayoritas subjek memiliki taraf penyesuaian diri tinggi sebanyak 78 orang $(62,4 \%)$. Tingginya kemampuan penyesuaian diri siswa asrama SMK Kesehatan Bali Medika Denpasar dapat ditinjau dari hasil kategorisasi kecerdasan emosional dan kemandirian siswa yang menunjukkan bahwa mayoritas taraf kemampuan siswa dalam kedua aspek mental tersebut adalah tinggi. Tingginya kemampuan kecerdasan emosional dan kemandirian siswa asrama membuat kemampuan penyesuaian diri siswa mayoritas berada di taraf yang tinggi.

Terdapat perbedaan pada hasil studi pendahuluan mengenai penyesuaian diri siswa tahun pertama SMK Kesehatan Bali Medika Denpasar dengan hasil kategorisasi data penyesuaian diri, dimana pada hasil studi pendahuluan siswa mengalami kesulitan dalam penyesuaian diri sedangkan pada hasil kategorisasi data mayoritas siswa memiliki taraf penyesuaian diri yang tinggi. Perbedaan tersebut dapat terjadi karena adanya perbedaan jenis pertanyaan yang digunakan ketika mengadakan studi pendahuluan dan pengambilan data penelitian. Studi pendahuluan menggunakan jenis pertanyaan umum yang mengarahkan siswa kepada bagaimana penyesuaian diri siswa pada tahun pertama memasuki lingkungan asrama, sehingga memungkinkan siswa untuk memberikan jawaban berdasarkan pengalaman siswa ditahun pertama memasuki asrama. Pengambilan data penelitian menggunakan skala yang dibuat berdasarkan indikatorindikator perilaku yang menggali lebih dalam mengenai penyesuaian diri siswa.

Rentang waktu yang siswa alami pada masa awal memasuki asrama dengan pada saat pengambilan data dilakukan adalah kurang lebih enam bulan sehingga pada rentang waktu tersebut, kemampuan penyesuaian diri pada siswa berangsur-angsur berkembang sejalan dengan perkembangan kemandirian dan kecerdasan emosional siswa serta kondisi lingkungan sekolah yang mampu memberikan kenyamanan dan keamanan bagi para siswa. SMK Kesehatan Bali Medika Denpasar mengedepankan kenyamanan para siswa selama berada di asrama dengan menyediakan fasilitas asrama seperti WIFI serta rutin mengadakan kegiatan menonton film bersama di aula sekolah. Kegiatan dan fasilitas tersebut disediakan pihak sekolah dengan tujuan untuk membuat para siswa merasa nyaman selama jauh dari keluarga. Schneiders (1964) berpendapat bahwa salah satu faktor yang dapat memengaruhi penyesuian diri pada individu adalah kondisi lingkungan. Keadaan lingkungan yang baik, damai, tentram, aman, penuh penerimaan dan pengertian, serta mampu memberikan perlindungan kepada anggotaanggotanya merupakan lingkungan yang akan memperlancar proses penyesuaian diri.

Berdasarkan hasil uji data tambahan yang telah dirangkum pada lampiran 16, diperoleh bahwa hasil uji independent sample t-test pada penyesuaian diri ditinjau dari jenis kelamin menunjukkan skor probabilitas adalah 0,387 $(>0,05)$. Hal ini berarti tidak ada perbedaan yang signifikan pada penyesuaian diri ditinjau dari jenis kelamin. Menurut Schneiders (1964) terdapat beberapa faktor yang lebih memengaruhi penyesuaian diri antara lain adalah keadaan 
fisik, perkembangan dan kematangan, keadaan psikologis, keadaan lingkungan dan tingkat religiusitas dan kebudayaan.

Berdasarkan hasil uji data tambahan yang telah dirangkum pada lampiran 16, diperoleh bahwa hasil uji independent sample t-test pada penyesuaian diri ditinjau dari pendidikan ayah menunjukkan skor probabilitas adalah 0,835 $(>0,05)$. Hasil uji independent sample t-test pada penyesuaian diri ditinjau dari pendidikan ibu menunjukkan skor probabilitas adalah $0,137(>0,05)$. Hal ini berarti tidak ada perbedaan yang signifikan pada penyesuaian diri ditinjau dari pendidikan orangtua. Salah satu faktor yang memengaruhi penyesuaian diri menurut Schneiders (1964) adalah kondisi lingkungan salah satunya adalah keluarga. Orangtua merupakan anggota keluarga yang memiliki pengaruh besar dalam memberikan pola asuh kepada remaja dalam masa perkembangan dan pertumbuhannya. Tingkat pendidikan orangtua tidak memengaruhi bagaimana pola asuh yang diterapkan kepada remaja. Interaksi sosial dan lingkungan dapat memberikan informasi kepada orangtua tentang bagaimana cara mendidik remaja yang baik sehingga para orangtua memiliki wawasan dan informasi yang luas mengenai pola asuh yang tepat untuk mendidik remaja.

Penelitian ini telah mampu mencapai tujuan setelah melalui prosedur analisis data, yaitu mengetahui peran kemandirian dan kecerdasan emosional terhadap penyesuaian diri pada siswa asrama tahun pertama SMK Kesehatan Bali Medika Denpasar, peran kemandirian terhadap penyesuaian diri pada siswa asrama tahun pertama SMK Kesehatan Bali Medika Denpasar dan peran kecerdasan emosional terhadap penyesuaian diri pada siswa asrama tahun pertama SMK Kesehatan Bali Medika Denpasar.

Berdasarkan penelitian yang telah dilakukan, dapat ditarik kesimpulan bahwa kemandirian dan kecerdasan emosional secara bersama-sama berperan terhadap penyesuaian diri pada siswa asrama tahun pertama SMK Kesehatan Bali Medika Denpasar, kemandirian memiliki peran yang signifikan terhadap penyesuaian diri pada siswa asrama tahun pertama SMK Kesehatan Bali Medika Denpasar, kecerdasan emosional memiliki peran yang signifikan terhadap penyesuaian diri pada siswa asrama tahun pertama SMK Kesehatan Bali Medika Denpasar, penyesuaian diri pada siswa asrama tahun pertama SMK Kesehatan Bali Medika Denpasar mayoritas tinggi dengan persentase sebesar $62,4 \%$, kemandirian pada siswa asrama tahun pertama SMK Kesehatan Bali Medika Denpasar mayoritas tinggi dengan persentase sebesar 55,2\%, kecerdasan emosional pada siswa asrama tahun pertama SMK Kesehatan Bali Medika Denpasar mayoritas tinggi dengan persentase sebesar 51,2\%, tidak ada perbedaan yang signifikan terhadap penyesuaian diri siswa asrama tahun pertama SMK Kesehatan Bali Medika Denpasar ditinjau dari jenis kelamin, tidak ada perbedaan yang signifikan terhadap penyesuaian diri siswa asrama tahun pertama SMK Kesehatan Bali Medika Denpasar ditinjau dari pendidikan orangtua.

Berdasarkan kesimpulan yang telah dipaparkan, maka peneliti dapat memberikan saran untuk para siswa dimana siswa diharapkan aktif dalam kegiatan ekstrakurikuler khususnya ekstrakurikuler yang mengutamakan kerjasama kelompok dan memperbanyak kegiatan diskusi bersama teman-teman, baik dalam membahas materi pelajaran ataupun masalah pribadi. Kegiatan tersebut dapat membantu siswa dalam membangun hubungan sosial yang lebih luas untuk dapat mengurangi kecemasan dan tekanan yang dialami pada masa tahun pertama memasuki asrama.

Saran bagi orangtua yaitu diharapkan mampu lebih kooperatif dalam mendiskusikan emosi yang dirasakan dan permasalahan yang diamali baik di sekolah ataupun pribadi, sehingga anak dapat meningkatkan kecerdasan emosional dalam menghadapi masalah dengan lebih efektif. Orangtua juga diharapkan mampu memberikan kesempatan kepada remaja untuk mengemukakan pendapat agar remaja mampu memutuskan sendiri apa yang terbaik bagi dirinya. Kesempatan yang diberikan kepada remaja dapat dimulai dari hal-hal kecil seperti menentukan sendiri sekolah yang diminati, dalam hal ini orangtua tetap dapat memberikan saran, namun keputusan tetap berada di tangan remaja.

Saran bagi pihak institusi pendidikan yaitu diharapkan dapat memaksimalkan kegiatan-kegiatan maupun pelatihan yang mampu menunjang kemandirian, kecerdasan emosional dan penyesuaian diri siswa seperti kegiatan outbond dan ekstrakurikuler. Pihak institusi juga diharapkan lebih peka terhadap para siswa dengan mengadakan diskusi rutin bersama para siswa mengenai kendala ataupun permasalahan yang dialami siswa selama berada di asrama.

Saran bagi peneliti selanjutnya yaitu diharapkan mampu membuat item skala dengan bahasa yang sederhana agar lebih mudah dipahami oleh subjek khususnya remaja, peneliti selanjutnya diharapkan lebih teliti dalam mengawasi subjek selama pengisian skala agar tidak terjadi kelalaian yang dapat memengaruhi hasil penelitian, peneliti dapat melakukan penelitian dengan menggunakan subjek kelas XI adan XII untuk melihat gambaran perbedaan kemandirian, kecerdasan emosional dan penyesuaian diri pada setiap tingkatan kelas dan peneliti selanjutnya dapat melakukan penelitian dengan menggunakan faktor-faktor lain yang tidak diteliti pada penelitian ini yang mungkin berperan terhadap penyesuaian diri seperti efikasi diri, motivasi diri, konsep diri, pola asuh orangtua dan urutan kelahiran.

\section{DAFTAR PUSTAKA}

Agustiani, H. (2009). Psikologi perkembangan (pendekatan ekologi kaitannya dengan konsep diri dan penyesuaian diri pada remaja). Bandung: PT Refika Aditama. 


\section{KEMANDIRIAN DAN KECERDASAN EMOSIONAL TERHADAP PENYESUAIAN DIRI SISWA ASRAMA TAHUN PERTAMA}

Azwar, S. (2014). Penyusunan skala psikologi. Yogyakarta: Pustaka Pelajar.

Calhoun, J.F. \& Acocella, J.R. (1990). Psychology of adjustment and human relationships (3rd ed.). New York: McGraw Hill.

Dazeva, V. \& Tarmidi. (2012). Perbedaan kecerdasan emosional siswa ditinjau dari jenis kegiatan extrakurikuler. Psikologia-Online, 7 (2), $81-92$.

Desmita. (2009). Psikologi perkembangan peserta didik. Bandung: PT Remaja Rosdakarya.

Fatimah, E. (2006). Psikologi perkembangan: Perkembangan peserta didik. Bandung: Pustaka Setia.

Ghozali, H. I. (2005). Analisis multivariate dengan program SPSS. Semarang: Badan Penerbit Universitas Diponegoro.

Goleman, D. (2000). Working with emotional intelligenc: kecerdasan emosi untuk mencapai puncak prestasi. Jakarta: PT Gramedia Pustaka Utama.

Goleman, D. (2015). Emotional intelligence (kecerdasan emosional). Jakarta: PT Gramedia Pustaka Utama.

Hurlock, E.B. (1980). Psikologi perkembangan: Suatu pendekatan sepanjang rentang kehidupan (5th ed.). Jakarta: Penerbit Erlangga.

Islami, A.N. (2016). Hubungan sense of school belonging dengan misbehavior pada siswa sekolah menengah di pondok pesantren. Seminar ASEAN 2nd Psychology \& Humanity. Psychology Forum UMM, Universitas Muhammadiyah Malang.

Purwandari, E. \& Purwati. (2008). Character building: Pengaruh pendidikan nilai terhadap kecerdasan emosi anak. Jurnal Penelitian Humaniora, 9 (1), 13 - 31.

Puspitasari, J. (2015). Hubungan antara kecerdasan emosi dengan perilaku altruistik pada siswa siswi anggota pramuka (Skripsi tidak dipublikasikan). Fakultas Psikologi Universitas Muhammadiyah, Surakarta.

Rini, A.R.P. (2012). Kemandirian remaja berdasarkan urutan kelahiran. Jurnal Pelopor Pendidikan, 3 (1).

Rustika, I.M. (2014). Faktor-faktor yang mempengaruhi prestasi akademik pada remaja (Disertasi tidak dipublikasikan). Fakultas Psikologi Universitas Gadjah Mada, Yogyakarta.

Santoso, S. (2005). Mengatasi berbagai masalah statistik dengan SPSS versi 11.5. Jakarta: PT. Gramedia.

Santrock, J.W. (2007a). Remaja: Jilid 1 (11th ed.). Jakarta : Penerbit Erlangga.

Santrock, J.W. (2007b). Remaja: Jilid 2 (11th ed.). Jakarta: Penerbit Erlangga.
Saptoto, R. (2010). Hubungan kecerdasan emosi dengan kemampuan coping adaptif. Jurnal Psikologi, 37 (1).

Sasmita, I.A.G. Hutri D. (2015). Peran efikasi diri dan dukungan sosial teman sebaya terhadap penyesuaian diri mahasiswa tahun pertama Program Studi Pendidikan Dokter Fakultas Kedokteran Universitas Udayana (Skripsi tidak dipublikasikan). Fakultas Kedokteran Universitas Udayana, Denpasar.

Schneiders, A.A. (1964). Personal adjustment and mental health. New York: Hoolt, Rinehart and Winston.

Setiawan, I. (2013). Pembinaan dan pengembangan peserta didik pada institusi pendidikan berasrama. Yogyakarta: Smart Writing.

Solomon, L.J. \& Rothblum, E.D. (1984). Academic procrastination: Frequency and cognitive-behavioral correlates. Journal of Counseling Psychology, 31 (4), 503 - 509.

Steinberg, L. (2014). Adolescence (10th ed.). New York: McGraw Hill.

Wahab, S., Rahman, F.N.A., Hasan, W.M.H.W., et al. (2013). Stresors in secondary boarding school students: Association with stres, anxiety and depressive symptoms. Asia-Pasific Psychiatry, 5, $82-89$.

Wulandari, N.K. (2016). Studi pendahuluan memasuki sekolah berasrama (Naskah tidak dipublikasikan). Program Studi Psikologi Fakultas Kedokteran Universitas Udayana, Denpasar.

Zakiyah, N., Hidayati F.N.R., \& Setyawan, I. (2010). Hubungan antara penyesuaian diri dengan prokrastinasi akademik siswa sekolah berasrama SMP N 3 Peterongan Jombang. Jurnal Psikologi Undip, 8 (2). 